Chirurgia (2018) 113: 497-502

No. 4, July - August

Copyright@ Celsius

http://dx.doi.org/10.21614/chirurgia.113.4.497

\title{
Clinical Pattern of Surgical Crohn Disease Patients
}

\author{
Iulian Slavu', Adrian Tulin', Lucian Alecu', Daniela Mihaila', Vlad Braga', Theodor Voiosu², Luminita Tomescu', \\ Oana Stanciulea ${ }^{3}$, Silviu Constantinoi ${ }^{4}$
}

\author{
${ }^{1}$ General Surgery Clinic, Emergency Clinical Hospital Prof. Dr. Agrippa Ionescu, Bucharest, Romania \\ ${ }^{2}$ Gastroenterology Department, Colentina Clinical Hospital, Bucharest, Romania \\ ${ }^{3}$ General Surgery Clinic, Fundeni Clinical Institute, Bucharest, Romania \\ ${ }^{4}$ General Surgery Clinic, Emergency Clinical Hospital - Saint Mary, Bucharest, Romania
}

Corresponding author:

Alecu Lucian, MD, PhD

Department of General Surgery Agrippa

Ionescu Emergency Clinical Hospital

Bucharest, Romania, 011356

E-mail: lucianalecu@yahoo.com
Received: 27042018

Accepted: 10.06 .2018

\section{Rezumat}

\section{Pattern-ul clinic al pacientului chirurgical cu boală Crohn}

Backround / Obiectiv: Scopul studiului a fost de a evalua existența unui model clinic referitor la localizarea anatomică a bolii Crohn (BC) şi indicația chirurgicală împreună cu tipul de intervenție efectuat. De asemenea $\mathrm{s}^{-a}$ dorit investigarea comparativă a complicatiilor chirurgicale a pacienților din mediul rural şi urban. Metode: Datele au fost obținute din foile de observatie ale pacientilor care au fost procesate şi centralizate. Rezultatele statistice au fost obținute prin utilizarea testului CHY-SQUARE. Interpretările şi descrierea acestora au fost redate sub forma unui studiu longitudinal retrospectiv.

Rezultate: Lotul analizat face parte dintr-un studiu retrospectiv format din 60 de pacienți cu diagnostic de BC şi intervenție chirurgicală. Pacienții cu afectare predominant ileocolică au fost frecvent diagnosticați cu obstrucție şi au fost frecvent supuşi unei enterectomii cu anastomoză. Pacienții cu boală colonică au asociat frecvent perforatii şi au fost tratați prin rezecție şi colostomie. Pacientii din mediul rural au asociat complicatii chirurgicale mai rar, global ei au demonstrat o evoluție mai blândă față de pacienții din mediul urban.

Concluzii: Deşi majoritatea pacienților cu BC necesită o intervenție chirurgicală, indicația ar putea fi anticipată prin recunoaşterea conceptului de model clinic iar intervenția chirurgical ar putea putea fi prezisă în funcție de caracterele clinice ale bolnavului/bolii.

Cuvinte cheie: boala crohn, chirurgie, pattern 


\section{Abstract}

Backround/Objective: The aim of investigation was to evaluate if there is a pattern regarding the anatomical location of the disease and type of surgery performed/surgical indication. Also a analysis was performed regarding the complication rate in two subgroups deriving from urban and rural environments.

Methods: Data was obtained from the medical records of patients with CD and centralized. Tests of statistical analysis included the CHY-SQUARE test and the results were presented as a retrospective, longitudinal study.

Results: The group was formed of 60 patients. Patients with ileocolic disease were frequently diagnosed with obstruction and benefited from an enterectomy with anastomosis. Patients with colonic disease were frequently diagnosed with perforation and benefited from colectomy and stomy. Patients from rural areas had a milder evolution when compared with patients from urban enviroments.

Conclusions: Although most patients with CD eventually require surgery, the indication could be anticipated by recognition of the concept of clinical patterns, and type of surgery required could be predicted if the clinical aspect of the patient/disease were identified.

Key words: Crohn disease, surgery, pattern

\section{Introduction}

Crohn's disease is a chronic, incurable pathology that can affect any segment of the digestive tract but can also be located at distance from the digestive system (skin). The behavior of the pathology, depending on the complications produced, may be classified as: stricturising, non-penetrating or inflammatory, fibrostenotic or penetrating - these features, although confirmed at onset, may undergo changes throughout the course of the disease. At the time of diagnosis, approximately 19\% of patients have a stricturing or fibrostenotic pattern of the disease - these are the phenotypes that frequently lead to surgical complications - in time, as the disease evolves this number may increase to $88 \%$ - 20 years after diagnosis (1).

Different risk factors are associated with first surgery such as tobacco consumption, disease location, fibrostenotic phenotype as well as early use of step-down therapy with immunomodulators or glucocorticoids in high doses (2).

Treatment of CD continues to be a difficult problem. There have been multiple clinical trials which tried to define the reasons for surgery in these patients, what type of surgery should be performed and at what point in the progression of the disease should it be performed. Uncertainty still exists and decisions are often taken intraoperative solely by the surgeon, depending on the local evolutionary stage of the disease.

Janowitz, in one of the first published articles on the surgical complications of CD in the year 1974, mentioned that the patient was surgically treated for one of the major catastrophes of CD (perforation, obstruction, haemorrhage) but more frequently for lack of response to medical therapy (3). Fast forward to 2011 - this custom is now changing. In a meta-analysis on 30.000 patients who underwent (elective or emergency) surgery between 2002 and 2010 for CD complications there was seen a global annual decrease of $3.5 \%$ in surgical interventions. A marked reduction was found for surgical interventions in emergency settings of $10.1 \%$ - while elective surgeries paradoxically saw an increase of 3.7\% per year (4).

The aim of the study was to evaluate if there is a pattern regarding the anatomical location of the disease (small intestine, colon, 
rectum) and type of surgery performed (stomy, anastomosis, stricturoplasty). Also keeping in count the etiology of the disease and the fact that patients from high stress environments such as modern cities have a higher incidence of the disease and worse outcomes we wanted to see if patients from urban areas were more exposed to surgical complications than patients from urban environments. The results will help identify patients at an increased risk of surgery thus making therapy more suitable to be tailored to the individual.

\section{Statistical Analysis}

Statistical analysis was performed using IBM SPSS V20.0.

\section{Material and Method}

The article derives from a larger retrospective multicenter study - patient data was obtained from a 11 year period from 4 university hospitals in Bucharest, Romania. The variables investigated were retrieved from operative protocols, patient charts, hystopathology reports and imagistic investigations. Patients were included in the study if they had a diagnosis of CD and were operated due to complications of the disease either in emergency or elective settings. Patients diagnosed with CD with surgery due to other complications than CD were excluded.

\section{Results}

We identified a total number of 60 patients diagnosed with $\mathrm{CD}$ who went through at least one surgical intervention due to complications. The mean age of the patients in the study group was 40 years and the first surgical intervention was enconuntered around 30 years. Two incidence peaks were observed at 23 years and 50 years. The majority of patients were operated in emergency settings.

The most affected region of the bowel was the small intestine -37 patients of the total of 60 had small intestinal involvement. Younger patients tended to have the small intestine more frequently affected while older patients frequently had colonic involvement. The small intestine was most frequent operated due to obstruction and was most frequent treated by resection and anastomosis. On the colon the most frequent surgical complication was perforation. From the 14 cases of perforation 10 (70\%) were located on the colon. Resection with anastomosis or stomy had almost equal distribution on the colon.

Perianal involvement of $\mathrm{CD}$ was rarely encountered in the studied group (Graphic 1).

Around $75 \%$ of patients with small intestinal disease had a anastomosis $\mathrm{n}=24$ while $52 \%$ of patients with colon disease $\mathrm{n}=11$ had a stomy and all of the patients with rectal/perirectal involvement had a stomy. Thus we formulated the hypothesis that anastomosis is most frequent done on the small intestine. After running Chy-Square test it was observed that $33 \%$ of the cells had an expected count less than 5. The likelihood ratio value was 14,37 with a degree of freedom equal to 2 and $\mathrm{p}=0.01$ (Graphic 2).

For disease located on the colon, perforation was the most frequent surgical complication $47 \%, \mathrm{n}=10$. After running $\mathrm{Ch}$ - Square test, 5 cells had an expected count less than 5 . The likelihood ratio was 10.97 with a degree of freedom of 1 and a $\mathrm{p}=0.13$

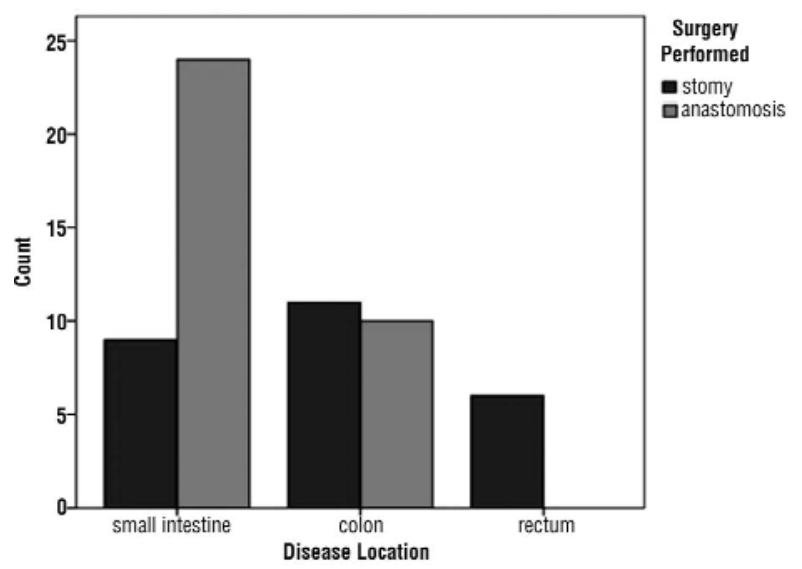

Graphic 1. The above graph looks for an association between disease location and surgical treatment: the majority of resections with anastomosis were located on the small intestine while the distribution was almost equal on the colon regarding anastomosis and stomy. 


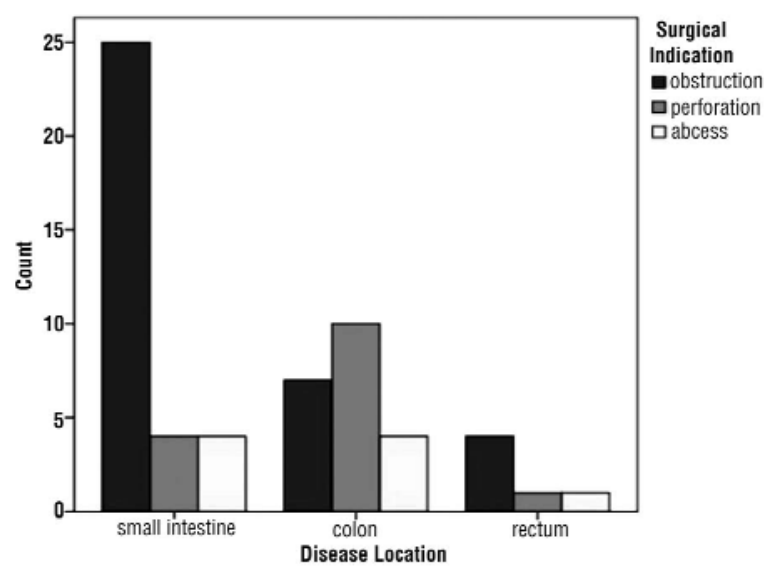

Graphic 2. The above graph looks for an association between disease location and surgical indication. The most frequent surgical complication on the small intestine was obstruction $-75 \%$ of cases, $n=25$

Regarding the social implications of the disease - patients from urban environments such as cities formed the bulk of the study and totaled $70 \%, \mathrm{n}=43$. Also they suffered more from surgical complications of CD - from the total of 20 reinterventions due to complications of CD 15 were seen in patients from urban environments. Also patients from urban environments tended to be diagnosed earlier with the disease with a median age at diagnosis of 25 years when compared to rural environments. Patients from rural environments were more frequently diagnosed in emergency settings.

\section{Discussions}

Surgical indications in CD include acute complications such as toxic colitis, haemorrhage and perforation or chronic complications: neoplasia, abdominal mass or stenosis. Another indication is the lack of response to maximum medical therapy. These complications were identified in the studied group of patients in varying percentages - but there was a tendency towards surgical interventions in emergency settings in contradiction with literature where there is a changing trend towards surgery in elective settings (1). The benefit of early surgery in selected ileocolic CD cases seems to offer future better results regarding surgical reinterven- tions and hospital admissions when compared to medical therapy as demonstrated by the study group of Vinna An et al. on 157 patients (5). This evolution of elective surgery is also sustained by Christopher Ma et. al in a large multicentric trial (4).

This trend towards emergency surgery in Romania was atributed by the authors to poor sanitary education of patients with $\mathrm{CD}$ and late presentation to specialized medical services in the diagnosis and treatment of CD. The mean age of the patients in the study group was 40 years and the first surgical intervention was enconuntered around 30 years. Two incidence peaks were observed at 23 years and 50 years - data correlated with the literature (6).

Many studies which sugest that intensely industrialized countries have a higher incidence of $\mathrm{CD}$ with patients who have a more agressive form of disease with frequent complications $(7,8)$. Taking into account that the group of patients studied came from the most varied environments - by dichotomizing it in urban and rural environments we noticed that urban patients were diagnosed more freaquently with $\mathrm{CD}$ and suffered more complications which required surgery.

This observation could be attributed to the fact that the hospitals from which the data was retrieved were from urban areas - but two of these were tertiary centers serving patients from all social environments.

There are several theories which try to explain this increased incidence in urban environments: - hygiene theory which is related to the fact that children in urban areas were less exposed to pathogens that would normally control the immune system of the digestive tract by continuous generation of new antigens - this lack of stimulation due to a sterile medium in childhood has made the adult which is exposed to new germs and antigens to have an exaggerated immune reaction which is directed towards its own structures not only the invaders (9).

Other risk factors which increase the occurrence of CD that are more common encountered in urban areas than rural areas are: smoking, 
widespread use of antibiotics, pollution, sedentary or stress $(10,11)$. Stress as a factor in the genesis of CD has begun to gain more and more importance being one of the highly studied aspects of psycho-neuroimmunology (12). According to new findings, lymphocytes and other inflammatory cells contain additional receptors for hormons and neuropeptides such as ACTH which belong to the hypothalamic axis which comunicates with the immune system via the ganglia located in the enteric nervous system of the digestive tract (13). Due to the structure of the study, stress could not be assessed as an independent factor - but in the future, more importance should be given to the psychosomatic side of the individual in the genesis of CD.

Perforation is one of the most feared complications of CD - in the studied group it was found more frequently is association with colonic involvment. In these situations, resection and stomy were the mainstay treatment. Anastomosis was tempted only if the disease was in the early stages and did not associate peritonitis. Surgery with stomy in cases with peritonitis associates a mortality of $4 \%$, whereas simple suture in an old perforated patient associates a mortality of $41 \%$ (14).

Literature also recommends percutaneous drainage - it was not performed in the study group. The procedure is indicated in hemodynamic stable patients, afebrile without septic shock. If conservative treatment is to be chosen, it should be remembered that $33 \%$ of patients require surgical reintervention at 1 year after percutaneous drainage (15).

The main complication of CD related to the small intestine which led to surgery was intestinal obstruction mostly due to strictures and intense inflamatory evolution of the disease in the intestinal wall which in time obliterated the lumen. The mainstay treatment was resection with anastomosis - stricturoplasty was largely avoided. Stricturoplasty has the disadvantage that it leaves the diseased segment in place but in some circumstances due to short intestinal syndrome it remains the only valid option. Where available and if the experience exists, laparoscopy is recommended for this procedure due to the advantages minimally - invasive surgery offers especially - cosmetics - which are so important for these young patients but get a back-seat when treatment is planned. Another advantage in the long - term is the reduced percentage of oclussions do to lower intestinal adhesions (16).

Dietz et al. from the Cleveland Clinic reported the results of stricturoplasty on 123 patients with 701 consercutive stricturoplasties done with a morbidity of $20 \%$ and a recurrence rate of $29 \%$ at almost 7 years thus recommending this surgical option as safe and durable (17).

The study has the limits of a retrospective study - the researchers could not control the exposure or outcome assement or the accuracy of recordkeeping thus making it subject to biases. Also the temporal relationship regarding the evolution of the subjects was difficult to evaluate. Due to the realtive small size of the sample, rare outcomes were dificult to evaluate such as the relationship between $\mathrm{CD}$ and perianal involvement.

\section{Conclusions}

Although most patients with CD eventually require surgery, the indication could be anticipated by recognition of the concept of clinical patterns, and type of surgery required could be predicted if the clinical aspect of the patient/disease were identified. As encountered in our study, patients with colonic involvement most likely require surgery with stomy for perforation while patients with small small intestinal involvement require surgery and resection with anastomosis due to obstruction. Patients from rural enviroments tend to have a milder evolution of the disese than patients from urban enviroments.

\section{Conflict of Interest}

The authors declare no conflicts of interests. 


\section{References}

1. Strong S, Steele SR, Boutrous M, Bordineau L, Chun J, Stewart DB, et al. Clinical Practice Guideline for the Surgical Management of Crohn's Disease. Dis Colon Rectum. 2015;58(11):1021-36.

2. Peyrin-Biroulet L, Harmsen WS, Tremaine WJ, Zinsmeister AR, Sandborn WJ, Loftus EV Jr. Surgery in a population-based cohort of Crohn's disease from Olmsted County, Minnesota (1970-2004). Am J Gastroenterol. 2012;107(11):1693-701.

3. Janowitz HD: Problems in Crohn's disease: evaluation of the results of surgical treatments. J Chronic Dis. 1975;28(2):63-6.

4. Ma C, Moran GW, Benchimol El, Targownik LE, Heitman SJ, Hubbard JN, et al. Surgical rates for Crohn's disease are decreasing: a population-based time trend analysis and validation study. Am J Gastroenterol. 2017;112(12):1840-1848.

5. An V, Cohen L, Lawrence M, Thomas M, Andrews J, Moore J. Early surgery in Crohn's disease a benefit in selected cases. World $\mathrm{J}$ Gastrointest Surg. 2016;8(7):492-500.

6. Quezada SM, Steinberger EK, Cross RK. Association of age at diagnosis and Crohn's disease phenotype. Age Ageing. 2013;42(1): 102-6.

7. Podolsky DK. Inflammatory bowel disease. N Engl J Med. 2002; 347(6):417-29.

8. Bernstein CN, Blanchard JF, Rawsthorne P, Wajda A. Epidemiology of Crohn's disease and ulcerative colitis in a central Canadian province: a population-based study. Am J Epidemiol. 1999; 149(10):916-24.
9. Gent $A E$, Hellier MD, Grace RH, Swarbrick ET, Coggon D. Inflammatory bowel disease and domestic hygiene in infancy. Lancet. 1994;343(8900):766-7.

10. Kaplan GG, Hubbard J, Korzenik J, Sands BE, Panaccione R, Ghosh $S$, et al. The inflammatory bowel diseases and ambient air pollution: a novel association. Am J Gastroenterol. 2010; 105(11):2412-9.

11. Li X, Sundquist J, Sundquist K. Educational level and occupation as risk factors for inflammatory bowel diseases: A nationwide study based on hospitalizations in Sweden. Inflamm Bowel Dis. 2009; 15(4):608-15

12. Goyal RK, Hirano I. The enteric nervous system. N Engl J Med. 1996;334(17):1106-15. Erratum in N Engl J Med 1996;335(3):215.

13. Ader R, Cohen N, Felten D. Psychoneuroimmunology: interactions between the nervous system and the immune system. Lancet. 1995;345(8942):99-103.

14. Greenstein AJ, Sachar DB, Mann D, Lachman P, Heimann T, Aufses AH Jr. Spontaneous free perforation and perforated abscess in 30 patients with Crohn's disease. Ann Surg 1987;205:72-76.

15. Gutierrez A, Lee H, Sands BE Outcome of surgical versus percutaneous drainage of abdominal and pelvic abscesses in Crohn's disease. Am J Gastroenterol. 2006:101(10):2283-9.

16. Lim JY1, Kim J1, Nguyen SQ. Nguyen Laparoscopic surgery in the management of Crohn's disease. World J Gastrointest Pathophysiol. 2014;5(3):200-4.

17. Dietz DW, Fazio VW, Laureti S, Strong SA, Hull TL, Church J, et al. Strictureplasty in diffuse Crohn's jejunoileitis: safe and durable. Dis Colon Rectum. 2002 Jun;45(6):764-70. 